\title{
Neo-liberalism and Ordoliberalism - One or Two Critiques? An Introduction
}

\author{
Vassilis K. Fouskas, University of East London, UK \\ Shampa Roy-Mukherjee, University of East London, UK
}

\begin{abstract}
This special issue addresses principally, but not exclusively, two themes: first, the differences and similarities between two stylised and separable, but no separate, class policies, that of Anglo-American neo-liberalism and German-Austrian ordoliberalism; second, whether or not EU Treaties and actual policies have been driven by German-Austrian ordoliberal principles. By way of examining these two themes, the contributions tackle also other important questions and puzzles, such as the wider impacts of those policies on society, or the tensions created between theoretical postulates and the practical implementation of them, or why neo-liberalism proved to be so resilient after the global financial crisis of 2007-8. They also endeavour to place these discussions in wider, global contexts. Our introduction provides a comprehensive summary of the arguments developed by the contributors and poses some further questions setting out a new research agenda in the field of critical sociological and economic studies.
\end{abstract}

\section{Keywords}

Neo-liberalism, ordoliberalism, class, power-shift, financialized capitalism, Keynesianism

\section{Prologue and Acknowledgements}

We have put together this special issue of Critical Sociology in order to shed light on a rather obscure debate within the ranks of progressive and heterodox scholarship, namely, the issue of ordoliberalism and neo-liberalism as stylised forms of public policy. Broadly speaking, there is a general consensus around the view that the historical-intellectual matrix of (AngloAmerican) neo-liberalism, glorified by Margaret Thatcher and Ronald Reagan, are to be found in the (German-Austrian) ideas and policy-making suggestions of ordoliberalism - or "the Freiburg School" - which emerged in the inter-war period and developed further after WWII. An intellectual movement at first, it attracted the interest of policy-makers and began influencing the formation of a new economic, political and ideological agenda alternative to all existing systematisations of theory and practice. In the inter-war period, the enemies were Keynes, Marx, laissez-faire liberalism and, to a substantial degree, the Nazi economic and political rule. In the post-world period, the ordoliberals concentrated rather on two enemies: Marxism and Keynesianism. Can, then, ordoliberalism and neo-liberalism be identified as constructivist projects, a view espoused by Ray Kiley in his recent work (Kiely, 2018)? How do 
they transpire in Anglo-American, German-Austrian and even European contexts? Moreover, what are the similarities and differences between those two stylised public policies?

These are very important questions. They lead not just to an assessment of the innerrelationship between the theory and practice of these two (class) public policies, but also to the generation of a number of other issues that the contributors to this special issue seek to answer. As the Euro-zone entered its tenth year of crisis and Britain posits itself for a hard Brexit, it has now become conventional to argue that German/Austrian ordoliberal policy principles - de-politicisation of economics, strict independence of the central bank mechanism, deflationary policy, strong state, competition policy, rule of law, to mention but a few - have long been institutionalised in the EU consolidating German hegemony. But if ordoliberal public policy in the Euro-zone and beyond manages EU processes and their crises - something which some contributors to this issue dispute - then what are its points of divergence and convergence with Anglo-American neo-liberalism - which some North American scholars identify as "New Constitutionalism"? (Gill and Cutler, 2014) If neo-liberal financialization as a class policy could not arrest the slow and protracted decline of the USA since the late 1960s, can German ordoliberalism re-launch the process of European integration, and on what policy basis? Are Foucault's analyses of the "ordo" phenomenon and "biopolitics" still relevant today? Last but not least, do we need one or two comprehensive critiques for these two separable, but not separate, public policies? These are some of the pertinent additional questions the authors participating in this collection are trying to address.

Initially, these questions were posed to them as starting points for a public reflection during a workshop they kindly agreed to participate on "Neo-liberalism and ordoliberalism: One or two critiques?", organised by the Centre for the Study of States, Markets and People (STAMP) at the University of East London (UEL) in December 2017. We thank all the participants in the workshop, who not only accepted our invitation producing excellent papers, but also cooperated professionally with us in every stage of the editing and reviewing process despite their busy schedules. STAMP's PhD students, led by Seun Alele, have been brilliant in taking care of the logistics and the organisation of the workshop, whereas UEL staff and students, as well as many other participants, created a warm and receptive scholarly atmosphere, participating energetically in the debate. We thank them all. We are also thankful to the Editor of Critical Sociology, David Fasenfest, who enthusiastically accepted to consider our proposal for a special issue and guided us with patience throughout the review and submission process. Last but not least, a note for the readers. The running order of articles is random. What follows may only be used as a guiding thread as to which article one should start reading first, second etc.

\section{Unveiling the Ordoliberal/Neo-liberal Conundrum}

Whereas neo-liberalism as class policy of the western states appeared historically in the early 1970s in Chile followed by other examples elsewhere and, crucially, in Britain and the USA in the late 1970s, ordoliberalism, in the form of "social market economy" appeared in Germany in the immediate post-war period. Lack of space prevents us from rehearsing here the history of those political, economic and ideological phenomena. However, it is important to point 
out, as Andrew Gamble and Bob Jessop do in their wide-ranging contributions, that GermanAustrian ordoliberalism provided the inter-disciplinary theoretical and practical matrix out of which the Anglo-American neo-liberals of the Chicago School were born. Incarnated into class policies, these ideas spread across diverse economic and political institutional settings in social contexts that other social theorists characterised as "varieties of capitalism" (Hall and Soskice, 2001). Other categorisations, especially over debates concerning "neo-imperialism" are: "shock therapy" - discussing the spread of neo-liberalism in East-Central Europe and the Balkans (Gowan, 1999; Fouskas 2003); or "the Washington consensus" - discussing the spread and impact of neo-liberalism on the MENA region (Shampa-Roy Mukherjee, 2015). It should be clear, Bob Jessop argues, that we do not have one neo-liberalism or one ordoliberalism but many and they correspond to the different socio-historical and political settings within which each such class policy finds expression. But it is the plurality of the phenomenon that resembles a number of similar theoretical and empirical features enabling a common, panoramic critique of both of them. This is precisely what Mike Wilkinson is arguing in his contribution, who approaches the issue from the perspective of constitutional law.

Wilkinson maintains that the present crisis reveals a long pedigree of confluence between political authoritarianism and economic liberalism. Beginning with the polemic between Hermann Heller and Carl Schmitt published in 1933 and elaborating further, Wilkinson shows how ordoliberalism-cum-neo-liberalism are hollowing out democracy in favour of an authoritarian liberalism. Schmitt has recommended a strong state in order to protect a free market economy and Heller criticised him for liberal authoritarianism. This played out in Europe's post-war "constitutional imagination", Wilkinson's argument goes, dedemocratising constitutions out of fear of freedom that had not only a class character but also a psychological one: not only that elites fear and distrust the people, but also the people fear and distrust themselves. Keeping the political and the economic apart has proved crucial in putting together Europe's Constitution, and the Maastricht Treaty is a case in point: "The EMU", Wilkinson says, "is based on the separation of supranational monetary policy from domestic fiscal authority and the avoidance of moral hazard, by prohibiting monetary financing as well as debt sharing". Thus, when the Eurozone crisis hit, the European Constitution could not hold, revealing the deeper crisis of the "material constitution", which is the clash between ordoliberal norms embedded in the Treaties and the discretionary politics of neo-liberal structural adjustment. In this context, Wilkinson argues, "democracy is displaced into an imperial regime of integration". This is what Pierre Dardot and Christian Laval called "the depletion of liberal democracy" and Kees van der Pijl "Eurozone authoritarianism" (Dardot and Laval, 2017: 301-21; Pijl, 2018: 13-39). Vassilis K. Fouskas and Bülent Gökay went as far as to see in Germany's export-led market strategy a form of cannibalisation which, under wage suppression at home, led to a peculiar form of exception across Europe in the context of a global competition between Germany/EU, the USA and China (Fouskas and Gökay, 2015; Fouskas \& Gökay 2019). Wolfgang Streeck has also traced the the development of ordoliberal Europe back to Carl Schmitt and Friedrich von Hayek and argues that all major European institutions, including the European Parliament, are in the service of "insulation of a politically instituted market economy from democratic politics" (Streeck 2015: 365). The European Parliament has no "executive control" or governing majority and lacks the right of "legislative initiative". The European Council, which consists of the heads of national governments and often engages in "secret negotiations", decides for 
economic governance and nothing can change at national level once a decision is taken. Social struggle, Streeck's argument goes, is suppressed in that it becomes an international diplomatic affair aloof from domestic-national settings. The European Commission, although subservient to the Council, has assumed the role of a kind of "watchdog" by way of "safeguarding and extending its powers and functions" creating instruments of intervention in order to liberate national economies "from national political market distortion" (Streeck 2015: 361). Then, there is the European Court of Justice, which is an "authoritarian institution" in itself as no parliament can overrule it. Its "original normative capital was competition law of the kind developed by the German ordoliberal school". This remit has been broadened and extended over the decades by using its monopoly to institute competitive markets, superintending the so-called four freedoms in the EU (free circulation of goods, services, capital and labour). Last but not least, Streeck lists the ECB as a key ordoliberal institution, "the kingpin of the EMU", as he calls it. Because it is a bank "without a state", it makes it the "most depoliticised and independent central bank in the world". "The Euro", Streeck continues, has nothing to do with Keynesian money; it is only "a means of exchange and a store of value; it is in particular not suitable for democratic market correction, for example in pursuit of full employment" (Streeck 2015: 369). Similar arguments we find in the works by Heiner Flassbeck and Costas Lapavitsas, especially in Lapavitsas' most recent work, The Left Case Against the EU (2019), which tackles the issue of ordoliberal discipline for the first time in his writings on the Eurozone crisis and its consequences (Flassbeck and Lapavitsas, 2015; Lapavitsas, 2019).

The contributions by Gareth Dale and Andy Storey are taking a different tack. Although they recognise as a fact that ordoliberal thinking influences EU policy-making and institutions, they maintain that this influence is rather exaggerated. Storey draws a methodological insight by the late Peter Gowan who, in his analysis of the Dollar-Wall Street Regime (DWSR) in 1999 and, later, of the global financial crisis (2009) argued that whereas the DWSR was legitimated by free-market neo-liberal outlooks, these did not seem to have been operative ideologies for its practitioners (Gowan, 1999; Gowan, 2009; Storey, in this issue). Similarly, Dale refers to ordoliberalism as "liturgy", arguing that the "ordoliberal book functions more as an ideology of justification than a manual of operation" (Dale, in this issue). Although Dale and Storey share the same point of view, they frame their analyses differently. Dale pursues a rather theoretical-notional path via Michel Foucault, who distinguished between German ordoliberalism, Anglo-American neo-liberalism and $19^{\text {th }}$ century liberalism (Foucault, 2010; Dale in this issue). Storey has a more pragmatic-empirical approach showing the extent to which ordoliberal practice in the EU fails to match with some sort of precision its notional postulates. Ordoliberal rules, Storey argues, are not written in stone and can be bent. For example, despite the fact that the EU has produced a number of new treaties in order to deal with the Eurozone crisis, they were implemented unevenly and arbitrarily: deficit fines, for example, were not automatically imposed on Spain and Portugal in 2016, despite their breach of the Fiscal Compact Treaty (Storey in this issue). Dale, however, questions Foucault's approach to liberal economists on the $19^{\text {th }}$ century arguing that they represent a plurality of views and practices and not a homogenised body as Foucault saw them. In particular, using a Gramscian insight on classical liberalism as a "form of state regulation", Dale argues that it should not be surprising the fact that ordo-economics require a strong state to institute a strong market: after all, "the invisible hand of the market is attached to the state" (Dale, in this issue). Similarly, Dale is rather sceptical in embracing wholesale the proposition that 
ordoliberalism represents a "Third Way" between laissez-faire liberalism and socialist planning. Karl Polanyi, too, Dale says as an expert on Polanyi's work, advocated a "Third Way" between laissez-faire and a "totally planned economy". Further, had ordoliberalism been a "Third Way" project, ordoliberals would have opted to align with the non-Aligned movement during the Cold War - instead, they chose NATO. The alternative reading of ordoliliberalism Dale offers is through the "Burkean fusion" (after the name of Edmund Burke), as he calls it, between "economic liberalism and political conservatism" and, in this respect, Dale agrees with Wilkinson's and Storey's verdicts that, in the end, ordoliberalism suffers from a great dose of political authoritarianism and undemocratic practice.

Arguably, the de-politicisation of (political) economy and the de-democratisation of institutional processes are not a common feature of ordoliberalism alone. It is also an important characteristic of Anglo-American neo-liberalism. Theoretically, they are embedded in the work of Carl Schmitt in the inter-war period, whose proposition that "sovereign is the one who makes the decision on the state of exception" in order to save liberal capitalism is no doubt bordering on ordoliberal thinking (Bonefeld, 2016: 747-761; Streeck, 2015: 361370). In fact, and in practice, since neo-liberalism was historically born out of the ordoliberal notional matrix, both class policies are bound to have more points of convergence than divergence: the "anti-inflation bias", "sound money", "balanced budgets", "central bank independence", "export-led growth", "rule of law and competition policy", "rule-based regulation of the economy", "entrepreneurialisation of the citizenry" - Foucault's bio-political claim - "competition policy" to mention but a few, are all policies shared by both stylised paradigms. The differences in the application and even outcomes is a reflection of different sets of institutional-bureaucratic and personal mediation, as well as, crucially, of the divergent cultural and economic structures that pertain to the uneven (imperial) organisation of capital accumulation on a global scale.

Yet, Bob Jessop, in his theoretically informed contribution, will argue that the key point of departure of neo-liberalism from the ordo-matrix is that it constitutes a strategy of disruption rather than stabilisation. To be precise, Jessop highlights an important distinction between Ordoliberalism (with capital $\mathrm{O}$ ) and neo-liberalisation: "the former comprises a relatively stable mode of societalisation, seeking to consolidate a stable spatio-temporal and institutional fix for a competitive market order;" whereas the latter targets social arrangements, "institutionalised social compromises" and diverse policies that "block the one-sided privileging of exchange-value (monetary gain) over (social) use-value". Clearly, Jessop sees this strategy as deriving from neo-classical economics and its notional obsession with perfect competition, especially in the era of finance-led capitalism. In addition, he sees Ordoliberalism as being more historically attuned to the interests of "profit-producing capital" and neo-liberalism to "the interests of money-capital" (Jessop, in this issue). This makes sense, not least because, as we saw earlier, ordoliberalism, through its "social market economy" spinoff, has been operational in (West) Germany since the immediate post-war period, whereas neo-liberalism coincided with the dollar crisis in the late 1960s and the collapse of the Bretton Woods system. Still, Jessop notes, both are class politics at their best in that they lent support for authoritarian and openly dictatorial governments, as was the 
case with both Milton Friedman, the master-head of the neo-liberals of the Chicago School, and Friedrich von Hayek, the founder of the Mont Pelerin Society in Switzerland in 1947 and arch-ordoliberal. Jessop observes a clear set of ordoliberal-authoritarian elements operating across the institutional settings of the EU, such as competition policy, central bank independence, control over state budgetary procedures etc., but at the same time he remarks that ordoliberalism cannot be seen separately from the global hegemony of neo-liberalism and financialisation: "the EU", he concludes, "cannot be reduced to a single theoretical or policy paradigm" (Jessop, in this issue); rather it is "over-determined" - the term belongs to Louis Althusser - by the American (neo-liberal) factor. All in all, for Jessop, (German-Austrian) ordoliberalism is far more organised that (Anglo-American) financialised neo-liberalism, an assertion that takes us back to his key point, namely that ordoliberalism aims at strategic generation of social stability, whereas neo-liberalism refers to strategic generation of social disruption.

Werner Bonefeld is the only contributor to this special issue that has been working on the ordoliberal phenomenon almost since the inception of the global financial crisis and the Eurozone crisis (Bonefeld, 2017). It was then, he rightly remarks in his opening comments, that "an abundance of literature about ordoliberalism and the ordoliberalisation of Europe" appeared.

This is no accident. Ever since the end of the fixed exchange rate system - late 1960s and officially with the end of Bretton Woods in August 1971 - the linchpin of globalisation/financialisation has been the banking sector. The global financial crisis, whose epicentres were in Wall Street and the City of London, trickled down to the Eurozone via the banking sector (Lapavitsas, 2010; Fouskas and Dimoulas, 2012; Fouskas \& Dimoulas, 2013). Europe's ordoliberal Treaties failed to protect the Eurozone and the "sound money" policy of the European Central Bank (ECB) went out of the window. German and French banks were exposed to the toxic assets they had bought from British and American banks. The periphery was the one to suffer: the bailout agreements signed between the troika (ECB, IMF, EU) and the weak countries of the periphery (Ireland, Greece, Spain and Portugal) transferred the debt from the private onto the public sector making the taxpayer responsible for its payment through a harsh policy of austerity and excessive taxation. As the crisis revealed the weakness of the so-called "French-German axis" and the prominence of the German state in managing the crisis, new Treaties had to be envisaged in order to corroborate the prudent management of money and legitimise the bondage of austerity, while making the banking sector of the European core solvent. The strategic aim was to uphold the value of the Euro as a reserve currency and dollar competitor in global currency markets and trade. In this equation, global competition from China also figures prominently (Fouskas and Gökay, 2019). Herein lies the deep authoritarian character of the new ordoliberal Treaties introduced in the wake of the crisis (the Fiscal Compact, the European Semester programme and so on). The extraordinary value of Bonefeld's contribution to this discussion is his assertion that ordoliberalism has not been the operative theory of German policy-makers at key points of the European monetary design or in the policy response to the Euro-crisis (Bonefeld, in this issue). Thus, Bonefeld sits at the other end of Wilkinson's and Jessop's argument, whereas somewhere in the middle we can place Dale's and Storey's claim, namely, that the influence of ordoliberalism in the 
institutional architecture of the EU is exaggerated. How does Bonefeld structure his argument?

For Bonefeld, the EU/Eurozone is not an esoteric and inward-looking economic-institutional structure. It is an international economic and political organisation operating in the maelstrom of global competition. Thus, "it is not ordoliberal Europe that limits the policy options of the democratically constituted member-states" but world-market conditions and competition that "compels each nation-state to achieve competitive labour markets", which is, of course, the source of (class) austerity. Naturally, in conditions of severe crisis, global competition becomes harsher and so does austerity. Further, Bonefeld argues that the premise of the view that ordoliberalism is the revealed truth of German economic policy in Europe is unclear in that it fails to recognise "the member states as the constitutive entities of European supranationalism" (Bonefeld, in this issue). Thus, the "ordoliberal" idea of "sound money" is not ordoliberal at all, because "sound money" is the cornerstone of every economic theory and is espoused by every sane political elite: "for the sake of sound money, money has to be taken out of mass democratic politics" (Bonefeld, in this issue). It is in this context that von Hayek and Wilhelm Röpke explore the idea of inter-state European federalism opposing the idea of a centralised, sovereign European power and promoting instead an idea about European integration that is only possible on a "market-economic basis". This, of course, is precisely what the British state has advocated ever since it entered the EEC/EU and faced the debates on the enlargement of European communities. Europe integrates the member-states as the "federated executives of supranational rules" placing the elaboration of economic policy in the domain of supranational rules ("subsidiarity"), precisely in order to maintain the bloc's global competitive position.

This analysis opens up a new analytical complexity, proposing to explore the neoliberal/ordoliberal conundrum from a world market perspective. Alan Cafruny and Leila Simona Talani argue that Germany used ordoliberal policy-making rules selectively/deselectively to serve its neo-mercantilist, export-led strategy inside and outside the EU. This selection/de-selection has resulted in a current account surplus of almost $8 \%$ of German GDP, leaving the periphery in permanent deficits, forcing it to cope with an enduring (and unsustainable) policy of austerity. This is an aspect shared by most contributions to this issue - Jessop, especially, makes a particular case about the permanency and enduring character of austerity across Europe, the most severely affected being the periphery and Greece in particular. In this qualified context, Germany is trying to cope with two issues that, essentially, overwhelm her. The first, Cafruny and Talani argue, is Germany's bid to compete internationally via ordoliberal austerity; and the second is the extent to which the structural needs of German capital can meet the political need of the EU/Eurozone as a whole. This is a tall order. As the authors underscore, Germany is facing a number of problems, such as low investment and productivity - her key vulnerability - a fact that is "illustrated more vividly in her core automobile sector", challenged by Trump's recent trade war (Cafruny and Talani, in this issue). Despite the fact that relocation of German industry to Central and Eastern Europe enabled German capital to compete internationally more effectively, Germany appears too weak for integrating politically the continent and the construction of a "European transnational capitalist class" remains a chimera. The differences of various fractions of 
national capitals in the EU remain a reality, the best example being the Brexit phenomenon or the new Italian ruling class supported by Italy's industrial North, both of which employ political discourses with pronounced elements of conservatism and even racism. All in all, according to Talani and Cafruny, it is not ordoliberal management that determines German policy; rather, it is the structural requirements of German capitalism and the class interests that correspond to it (low inflation, low wage, export-led) that makes selective/de-selective use of ordoliberal policy-making principles so useful.

But what is it that makes neo-liberalism so resilient? Why did we not experience a U-turn in the state's - and the EU's, in this regard - economic policy from supply-side economics to aggregate demand management as a cure for the crisis? Contrary to the aftermath of the 1929-33 global financial crisis which saw the introduction of Roosevelt's New Deal and Keynesian policy-making, the aftermath of the current crisis saw nothing similar: supply-side economic reforms deepened further; austerity measures increased; zero-time contracts, precarious work and part-time work proliferated; privatisation of public assets continued unabated; and more and more private agencies entered the milieu of the welfare state, the redoubt of European social democracy. Certainly, one could argue that this is because the neo-liberal view about the causes of the crisis was not due to the structural contradictions embedded in financialised capitalism but due to the "fact" that there was a lot of regulation where it should have been less or none, and less regulation where it should have been more. At least this is, by and large, the neo-liberal explanation about the causes of the crisis. Gamble begs to differ. He gives us five reasons for neo-liberalism's resilience.

The first is the role of the state and its central bank. By injecting billions into the ailing banking sector through the so-called "quantitative easing" (QE), the state acted as a real lender of last resort saving free market capitalism from an almost certain collapse. This was the case with the American Fed and the English central bank. The ECB, too, from 2015 onwards when Eurozone banks were on the verge of collapse, exhibited a selective purchasing of asset-paper from commercial banks - although it is a question whether Europe's experiment of QE was as efficient as the Anglo-American one. 'The second factor is geopolitical. According to Gamble, and unlike the 1930s, the current crisis did not signal a systemic change in the hierarchy of state power. The USA remains the top power in the international system, and despite the increasing significance of China and other Asian economies. The absence of another economic model based on a different type of economic and political organisation enabled neoliberalism to sustain its primacy. A third reason buttressing the resilience of the neo-liberal paradigm is the lack of a business class, whether national or transnational, interested in policy change. This, obviously, was not the case in the 1930s and 1970s. In the former case, the financial crisis led to the introduction of Keynesian policy-making (intervention in the aggregate demand management and cultivation of national business interests); in the latter, the pre-existing ordoliberal/ordoliberal system of thought backed up by financial capital got operationalised through neo-conservative political elite mediation. The collapse of the Lehman Brothers in 2008 did not induce the neo-liberal elites to change the fundamentals of their class policy by way of abandoning ordoliberalism/neo-liberalism as guidance. 
The last two factors contributing to the resilience of neo-liberalism are political and ideological. By political, Gamble means the adoption by all big parties - especially the (Centre) Left and the (Centre) Right - of all key neo-liberal policy tenets, effectively subscribing to TINA (There is No Alternative). TINA signals a technocratic conception of economic policy which reduces economics to quantifiable policy propositions deprived of any socio-political relation, an approach at the basis of which is the concept of sound money. By "ideological" Gamble offers a rationale that is worth quoting in full:

$[\mathrm{N}]$ eo-liberalism is chameleon like in its ability to take many forms and incorporate many different forms of liberalism. It also operates successfully on a number of levels. It is a set of doctrines, some of them developed at a high level of abstraction. It is also a set of policy tools. Most important of all it is expressed as a form of common sense derived from the lived experience citizens have of being buyers and sellers and market agents. These experiences are associated with certain forms of individualism, autonomy, self-reliance and the notion of equal rights. The ability of neo-liberalism to appear progressive, offering opportunity and choice has been very important to its success, and has become implanted in the lives of most citizens in a more complete way than ever before (Gamble, in this issue).

\section{By Way of a Conclusion: Towards a New Research Agenda for the Left}

If anything, this special collection on ordoliberalism/neo-liberalism shows how difficult it is to classify these two stylised public policies; decipher their meanings; diagnose their impacts on policy-making and trace their intellectual origins. But perhaps this is the case with every significant social theory that has influenced the course of social and political history.

Ordoliberal social scientists were not Marxists and fought against the nationalisation of enterprises and the land alongside the Stalinist model. They were not Keynesians because they were in favour of balanced budgets (against deficit spending), viewing intervention in aggregate demand management as a factor that leads to state profligacy, high inflation and rising debt. And, by and large, were not laissez faire liberals either because, according to all ordoliberals, the economic liberalism of the $19^{\text {th }}$ century collapsed in the experiment of the hyperinflation of the Weimar Republic in the 1920s. Some ordoliberals argued that not all competition is good; competition may need oversight and strict regulation, hence the "antitrust" regulation they proposed (and which is inserted into EU Treaties). And, although some of them had sympathies with the Nazi party and even joined it, overall, the ordoliberals fought against the Nazi world-view and some of them went even to exile. Most ordoliberal and neoliberal thinkers - we include here "public choice" theorists, such as James M. Buchanan and the "Virginia School" - held important university positions, especially at Freiburg, Cologne and other universities in Germany and Austria, and in Chicago and other Ivy League institutions in the USA; they produced journals; raised funds and set up a semi-secret gathering at Mont Pelerin, Switzerland, outlasting its founder, von Hayek; influenced directly the cabinets of the most powerful states in the world, including the USA and Britain (although 
the first ordoliberal experiment took place in Chile); whereas Alfred Müller Armack, an interwar ordoliberal economist and, accidentally, a supporter of the Nazi regime, led (West) Germany's delegation during the Treaty of Rome negotiations in 1956-7. Germany's Chancellor from 1963 to 1966, Ludwig Erhard, had openly declared his sympathies to ordoliberalism and its practical-policy spinoff, the "social market economy", is also inserted in the EU Treaties. Angela Merkel, Germany's Chancellor at the time of writing, proclaimed that "the ordoliberal principles of the Freiburg School have lost nothing in currency and importance" (Dale, in this collection). Nevertheless, with a new economic and geopolitical crisis looming, we need to start work on a new research agenda, elements of which can already be found in nuce in the articles of this collection.

1. We need to identify carefully the structural determinants of global politics and economics today, as well as their cultural and ideational premises. This is paramount, not least because, in our view, the USA had entered a historical period of irreversible decline in relation to the rise of China and, more broadly, Asia, although no global power or alliance of states is ready to takeover from the USA the management of global capitalism. The USA still rules. In this respect, Andrew Gamble is right to assert that, unlike the 1930s, there is no change in the hierarchy of global power-politics. But this is a structuralist comment: it indicates how things are at present. However, there is dynamic change in terms of the global distribution of power relations taken as a whole (Frank, 1998; Fouskas and Gökay, 2005; Arrighi, 2007; Fouskas and Gökay, 2012; Fouskas and Gökay, 2019). From this perspective, we are, as Gramsci put it, at an interregnum, hence the so many "morbid symptoms" within the Euro-Atlantic heartland (Trump, Brexit, neo-Nazi and racist movements across Europe, the refugee crisis, the enduring conflicts in Eastern Europe, Central Asia and the MENA region and so on). In one way or another, almost all contributors to this special issue recognise the increasing importance of China and Asian-centred global production networks, but the nature of the enquiry provided no room for deepening such an analysis. China's twin strategy - partaking in almost every international institution serving the USA's globalisation strategy while at the same time pursuing an independent expansionist agenda, especially via the Belt and Road Initiative and the "Made in China 2015" - is upsetting any stabilisation effort by Euro-Atlantic administrations that find it hard to deal with the aftermath of the financial crisis at a time when the Euro-zone crisis is still on. This said, global politics can no longer be premised on the binary Schmittian divide of "friend-enemy", as was the case during the Cold War ("us against Communism") and after 9/11 ("us against the terrorists") - domestic politics is a different ballgame (see below). Global migration movements, cultural shifts and new generations with multiple identities structure the premises upon which new international, regional and national policies should be envisaged by progressive civic agencies and political parties. Fundamentally, social theory and practice must disengage from Eurocentric analyses and approaches (Frank, 1998; Hobson, 2012; Fouskas and Gökay, 2019).

2. A further research question to be explored, given the above non-Eurocentric point of view, is how and towards which direction the European project can be reformed. We 
are entering here a very controversial subject. The European Commission has answers: just visit its website and read the Treaties of the EU and other regulations or policy directives, what usually goes under the so-called acquis communautaire. But if all is as rosy and smooth as the Treaties say, then by "reform" we would mean an advancement of the existing EU policies and norms towards the same neoliberal/ordoliberal direction, that is, austerity. This is not what we have in mind. By reform of the European project we mean further research on two contradictory claims within the European Left movement. The first, with which some of the contributors to this issue might actually agree, is reforming the EU/Euro-zone from within its existing institutional and political structures, boosting its social policy, increasing its budget (currently only 1\%); creating a fiscal and a political union backing the Euro-currency; creating a banking union, overall, reforming the Treaties and regulations in a social democratic direction. Yanis Varoufakis, Greece's former finance minster during the first seven months of the Syriza experiment that attempted to bend the EU's ordoliberal rulebook, is the foremost advocate of such a perspective (Varoufakis, 2016; Varoufakis 2017; Fouskas 2017a; Fouskas 2017b). He envisages a union along Keynesian lines in which the surpluses of the core would be recycled for the benefit of the indebted periphery, followed by policies of public investment. The second, which also some contributors to this issue might agree, is reforming the existing nationstates across the EU/Euro-zone by regaining national sovereignty and bringing the subaltern classes to the forefront of politics. This perspective, obviously, cannot be coordinated across Europe, simply because of the structural primacy this tendency attributes to uneven (economic, political and ideological) development, which necessitates primacy of social struggle within the national formation proper. It is a view popularised by such left-wing aggregations as the "Lexit" - as opposed to Brexit - campaign in Britain or the Popular Unity Party in Greece (Syriza's left-wing splinter after the referendum of July 2015 in which Syriza capitulated to the "Troika"). Prominent advocates of this tendency include Alex Callinicos and Costas Lapavitsas, the latter even articulating a book-length argument, The Left Case Against the EU (2019). Research is ongoing on these matters but the problem for further investigation we would like to pose here is the extent to which either of the above proposals - which are no doubt founded on both solid research and ideological preferences - can materialise without a radical transformation of the existing socio-political and economic orders, whether national or European. However, given the unevenness I the development of social and political movements across Europe and beyond, attempts at coordination would surely fail. This indicates that any left radical undertaking has to happen within its privileged space, and this is the remit of the nation-state. Social complexity and plurality of demands by the participatory subjects should not be in a position to dilute the class element as a key referent within a given social formation.

3. In this context, particular attention should be paid to what Andrew Gamble has identified as the fourth reason why neo-liberalism is so resilient. Essentially, he says that the adoption by both the Left and the Right of the same (neo-liberal/supply-side) political programmes and directions makes them converge to a conservative catch-all "centre". A quick look at British, US and European politics would convince us that one 
of the reasons why Trump and Brexit won in the USA and Britain respectively is because they employed a radical class discourse through which the subaltern classes, savaged by many years of austerity, could find expression. No doubt, this discourse is racist and authoritarian, but the Centre-Left of liberties, feminisms and identity politics failed to provide solutions to the everyday life of ordinary people. So, class still remains the key referent. The reasons for the rise of racist and right-wing movements across Europe are the same: harsh austerity dictated to governments by the banking sector and the ordoliberal Treaties of the EU, coupled with the disintegration of welfare provision and lack of full-time decent employment. From this perspective, research on the political and party-form of the historically progressive political agency - although a definition of progress might be another area of contention - has to be relaunched, taking into account the shifting parameters and the pluralism of the societal but without losing sight of the primacy of labour and class interests as the unifying identity referent of the social whole. This, in turn, means that we do not abandon the Marxian theory of value. If this does not happen, then not only neoliberalism will continue to dominate the institutional practice and cultural settings of the Euro-Atlantic world, but it may continue to do so under extremely right-wing and even supremacist regimes and ideologies. Supply-side economics can operate very well under both protectionist-nationalist and globalisation-pluralist regimes and ideologies.

4. Last but not least, we need to study green and gender alternatives that lead to the decolonisation/de-commodification of natural resources and the environment and the de-colonisation/de-commodification of bodies. Environmental degradation is the direct result of $\alpha$ socio-economic system geared towards exploitation and constant increase of the rate of profit. Neo-liberal and ordoliberal perspectives have nothing to say about this and the environmental policy of the EU - see, for instance, calls for use of sustainable renewable energy - remains a dead letter. Thus, research on this subject should be taken up by heterodox political economists and scholars. Similarly, ordoliberal/neo-liberal feminist agendas are completely inserted in the segmented logic of market relations deepening, instead of undermining, the social/technical/sexist division of labour in conditions of financialised capitalism. As a result of this, we witness a misconstrued position of gender and parenthood relations in both law and real life. Relinquishing the notion of equivalence in favour of an abstract equality, ordoliberal/neo-liberal discourses push for the feminisation of the markets - dominated by the service sector - as the key indicator of emancipation and equality, thus giving way to the commodification of reproduction disregarding class referents and the proletarianization of both motherhood and fatherhood. Whereas middle class families may be able to afford financing of reproduction also by way of excessive borrowing (nannies and babysitters, house cleaners, private nurseries and schools and so on), working class families, after the end of the Fordist wage, cannot fund their reproduction. Under Fordist regimes of accumulation, patriarchy was reproduced via an exchange of equivalence between the unpaid social labour of the woman and the paid social labour of the man. Post-Fordist regimes of flexible accumulation cannot sustain this model. And whereas patriarchy is crumbling, which 
is good, what appears to be replacing it is not gender equality inside and outside the household, but the proletarianization of the family, increasing divorce rates and a massive demographic problem - the fastest growing population group in the EuroAtlantic heartland is the population aged 65 years and over, that is, pensioners. ${ }^{i i}$ The consumer-centred approach of the ordo-neo-liberal project and the elevation of every citizen into a "responsible entrepreneur", pushes structurally both sexes to paid bondage (downward pressure on wages) as a counter-tendency to the falling rate of profit and investment (Fouskas and Gökay, 2019). It is worth noting that these views are currently colonising the entire world, from Brazil to Afghanistan and Gambia. This is no accident: neo-ordoliberal feminism is an imperial project. In this respect, a good starting point for left gender research would be to revisit the Marxian concept of value by way of attributing both real and semantic-ideational value to reproductive work that pertains to household and child-rearing. A good starter can be this empirical question: why making a meal for your family, or cleaning your family house, carries no social value - considered even by many as horrible routine chores - whereas being an accountant or a lawyer is not only (socially) valuable and valued in terms of income generation but also culturally valued by society? A perceptive analytical framework in approaching this issue from a de-commodified/de-colonising perspective is offered by Massimo de Angelis and his notion of commons and commoning (De Angelis, 2017)

If there is something about which ordoliberals and neo-liberals should be admired is that they not only took (and take) care to spread their ideas into politics, but also to produce and inject into politics and economics an inter-disciplinary research agenda. The papers we have edited here make an effort to address that problem from a left perspective. Further, our introduction has tried to fill some of the gaps we have been in a position to see. It is not enough and further work is required. At this point, it is worth reminding that Marx and Engels were two interdisciplinarian scholars par excellence, whereas Lenin's first important work, The Development of Capitalism in Russia, which he completed at the age of 27 , was a sociological masterpiece. This is what is missing today from radical left theory and practice and if this introduction has contributed some useful ideas towards this perspective, then surely it would have accomplished its aim.

\section{Notes}

\footnotetext{
i Daniel Lacalle of the Mises Institute observes: "The main reason why the ECB quantitative easing program has failed is that it started from a wrong diagnosis of the eurozone's problem. That the European problem was a demand and liquidity issue, not due to years of excess. The ECB had been receiving tremendous pressure from banks and governments to implement a similar program to the US's quantitative easing, forgetting that the eurozone had been under a chain of government stimuli since 2009 and that the problem of the eurozone was not liquidity but an interventionist model. The day the ECB launched its quantitative easing program, excess liquidity stood at 125 billion euro. Since then, it has ballooned to 1.8 trillion euro" (Lacalle, 2018).
}

\footnotetext{
ii Further distortions and misconceptions are embedded in Family Law and the legal process. For instance, shared parenting after divorce is not a presumption in law in very many countries, including the UK. This has as a result
} 
for children to follow almost always the mother as a custodian (residential) parent, with the father having only visitation rights (non-residential parent) and the duty to provide child maintenance. This despite the fact that the couple may have had shared parenting arrangements while in marriage. There are many other oddities and injustices, especially in financial matters on divorce, but the most anti-child-centric issue is the so-called "Leave to Remove" application. Family Law admits "Leave to Remove" applications, that entitles custodian parents to legally remove children from the jurisdiction in which both parents leave as long as one parent - or the custodian parent - desires so, for whatever reason. To all intents and purposes, the sole beneficiaries of those legal processes are family solicitors and barristers, making family another area of commodification for the extraction of profit. The primary losers are the children and then, of course, the parents. From whichever way you look at these issues, the proclaimed "child-centric" approach of the Family Courts goes out of the window in practice, not to mention the secrecy family Courts are surrounded - the pretext being the "non-exposure of children that are under-age".

\section{References}

Arrighi G (2007) Adam Smith in Beijing. London: Verso.

Bennett R. et al. (2019) Universities face credit crunch as debt spirals. The Times 3 January: 1, 8.

Bonefeld W (2016) Authoritarian liberalism from Schmitt via ordoliberalism to the Euro. Critical Sociology 43(4-5): 747-761.

Bonefeld W (2017) The Strong State and the Free Economy. London: Rowman and Littlefield.

Dardot P and Laval C (2017) The New Way of the World. On Neo-liberal Society. London: Verso.

De Angelis M (2017) Omnia Sunt Communia. On the Commons and the Transformation to Post-capitalism. London: Zed

Flassbeck H. and Lapavitsas C (2015) Against the Troika. Crisis and Austerity in the Euro-zone. London: Verso

Foucault M. (2010/1978-9) The Birth of Biopolitics. London and New York: Palgrave-Macmillan

Fouskas VK (2003) Zones of Conflict. US Foreign Policy in the Balkans and the Greater Middle East. London: Pluto press.

Fouskas VK and Dimoulas C (2012) The Greek workshop of debt and the failure of the European project. Journal of Balkan and Near Eastern Studies 14(1): 1-31

Fouskas VK and Dimoulas C (2013) Greece, Financialisation and the EU. The Political Economy of Debt and Destruction London and New York: Palgrave-Macmillan

Fouskas VK and Gökay B (2015) Cannibalisation and the state of exception. openDemocracy 30 November. https://www.opendemocracy.net/can-europe-make-it/vassilis-k-fouskasbulent-gokay/cannibalisation-and-state-of-exception 
Fouskas VK (2017a) A whistle-blower's tale. Fabian Review, Summer 2017: 28.

Fouskas VK (2017b) Varoufakis contra omnes. The Political Quarterly, 88(4): 743-745.

Fouskas VK and Gökay B (2019) The Disintegration of Euro-Atlanticism and New Authoritarianism. Global Power-Shift. London and New York: Palgrave-Macmillan

Frank AG (1998) ReOrient. Global Economy in the Asian Age. Berkeley: University of California Press

Gill S. and Cutler CA (2014) New Constitutionalism and World Order. Cambridge: C.U.P.

Gowan P. The Global Gamble. Washington's Faustian Bid for World Dominance. Londn: Verso.

Gowan P (2009) Crisis in the heartland. Consequences of the New Wall Street System. New Left Review, 55, January-February (accessed: 7 January 2019) https://newleftreview.org/II/55/peter-gowan-crisis-in-the-heartland

Hall PA and Soskice D (2001) Varieties of Capitalism. The Institutional Foundations of Comparative Advantage. Oxford: O.U.P.

Hobson J (2012) The Eurocentric Conception of World Politics. Western International Theory. Cambridge: C.U.P.

Kiely R (2018) The Neo-Liberal Paradox. Cheltenham: Edward Elgar

Lacalle D (2018) The ECB's quantitative easing was a failure, here is what it actually did. Mises Institute, 28 December https://seekingalpha.com/article/4230480-ecbs-quantitative-easingfailure-actually (accessed: 6 January 2019)

Lapavitsas C et al. (2010) Euro-zone crisis: Beggar thyself and thy neighbour. Journal of Balkan and Near Eastern Studies 12(4): 1-41

Lapavitsas C (2019) The Left Case against the EU. Cambridge: Polity press

Roy-Mukherjee (2015) Connecting the dots: the Washington consensus and the 'Arab Spring'. Journal of Balkan and Near Eastern Studies 17(2):141-158.

Streeck W (2015) Heller, Schmitt and the Euro. European Law Journal 21(3): 361-370

Van der Pijl K. (2018) Euro-zone authoritarianism and the neo-liberal project in Greece and Southern Europe. In Fouskas VK and Dimoulas C (eds) Greece in the $21^{\text {st }}$ Century. The Politics \& Economic of a Crisis. London: Routledge, 13-39.

Varoufakis Y (2016) And the Weak Suffer What They Must? Europe, Austerity and the Threat to Global Stability. London: Vintage. 
Varoufakis Y (2017) Adults in the Room. My Battle with Europe's Deep Establishment. London: Bodley Head.

For correspondence: Vassilis K. Fouskas, Royal Docks School of Business \& Law, Centre for the Study of States, Markets \& People (STAMP), University of East London, 1 Salway Road, London E15 1NF. UK. E-mail:v.fouskas@uel.ac.uk 